LINGUA, Vol. 15, No. 2, September 2018

p ISSN: 1979 9411; e ISSN: 2442 238X

Http://lingua.pusatbahasa.or.id; Email: presslingua@gmail.com

Center of Language and Culture Studies, Surakarta, Indonesia

Susdiana, Emilia Baiq; Hanafi, Nurachman \& Sudirman. 2018. Implementasi Kurikulum 2013 pada Mata Pelajaran Bahasa Indonesia di SMA di Lombok Tengah.

Lingua (2018), 15(2):207 224. DOI:10.30957/lingua.v15i2.527.

\title{
IMPLEMENTASI KURIKULUM 2013 PADA PEMBELAJARAN BAHASA INDONESIA DI SMA DI LOMBOK TENGAH
}

\author{
Baiq Emilia Susdiana ${ }^{1,}$ Nurachman Hanafi ${ }^{2}$ \& Sudirman $^{3}$ \\ Magister Pendidikan Bahasa Indonesia Universita Mataram \\ Jl. Majapahit No. 62, Gomong, Selaparang, Dasan Agung Baru, Selaparang, Kota \\ Mataram, Nusa Tenggara Barat 83115 \\ Email: $\frac{{ }^{1} \text { baiqemiliasus@,gmail.com; }}{\underline{2}{ }^{2} \text { nurachmanhanafi@yahoo.com } \underline{\&}}$
}

\begin{abstract}
This study reports how attainments in the implementation of the 2013 Curriculum (K-13) in teaching bahasa Indonesia for SMA students. Using a survey method, this study assigned teachers, students and administrators in SMAN 1 of West Brayat, Central Lombok regency. The results show that handicaps do exist to teach bahasa Indonesia based on K-13 because: (1) teachers get problems on preparing teaching instructional designs and its attributes such as lesson plan, scientific approach teaching method, audio-visual toolkits, learning resources, and authentic assessment; (2) lack of understanding to perceive $\mathrm{K}-13$ as an ideal curriculum that encourages students more active and self-independent kearners; and (3) constraints appear in the implementation of K-13 include limited time, limited facilities and infrastructure, assessment, and activeness of students in the teaching and learning process.
\end{abstract}

Keywords: curriculum, bahasa Indonesia, constraints, implementation.

DOI:10.30957/lingua.v15i2.527.

\section{PENDAHULUAN}

Penelitian ini bertujuan mengkaji pelaksanaan Kurikulum 12 (selanjutnya disebut K-13) dalam pembelajaran bahasa Indonesia di SMA di Lombok Tengah. Implementasi akan dilihat berdasarkan kesesuaian antara isi kuriukulum dengan praktik yang dilakukan guru di kelas dan ketersediaan sumberdaya di lapangan yang bermuara pada kendala implementasi K-13 di lapangan.

Pusat Kurikulum (2007:17) menegaskan salah satu dimensi yang tidak bisa dipisahkan dari pembangunan dunia pendidikan nasional di masa depan adalah kebijakan mengenai kurikulum. Kurikulum merupakan jantungnya dunia pendidikan. Untuk itu, kurikulum di masa depan perlu dirancang dan disempurnakan untuk meningkatkan mutu pendidikan secara nasional dan meningkatkan mutu sumber daya manusia Indonesia. 
LINGUA, Vol. 15, No. 2, September 2018

p ISSN: 1979 9411; e ISSN: 2442 238X

Http://lingua.pusatbahasa.or.id; Email: presslingua@gmail.com

Center of Language and Culture Studies, Surakarta, Indonesia

Susdiana, Emilia Baiq; Hanafi, Nurachman \& Sudirman. 2018. Implementasi Kurikulum 2013 pada Mata Pelajaran Bahasa Indonesia di SMA di Lombok Tengah.

Lingua (2018), 15(2):207 224. DOI:10.30957/lingua.v15i2.527.

Kurikulum merupakan seperangkat rencana dan pengaturan mengenai tujuan, isi, dan bahan pelajaran serta cara yang digunakan sebagai pedoman penyelenggaraan kegiatan pembelajaran untuk mencapai tujuan pendidikan nasional (UU No 20/2003: Pasal 1 ayat 19). Agar senantiasa sesuai dengan perkembangan zaman, kurikulum senantiasa berubah. Sejak zaman Indonesia merdeka, urikulum sudah mengalami 11 kali perubahan. Terakhir kurikulum berubah dari kurikulum KTSP menjadi Kurikulum 2013. Idealnya perubahan kurikulum direncanakan secara matang. Hal-hal yang perlu dilakukan dalam perubahan kurikulum misalnya evaluasi menyeluruh terhadap kurikulum lama, analisis kebutuhan terhadap tantangan zaman, penyusunan perangkat kurikulum, dan sosialisasi secara optimal.

K-13 pada dasarnya merupakan upaya penyederhanaan dan tematik integratif yang disiapkan untuk mencetak generasi yang siap di dalam menghadapi masa depan. Karena itu kurikulum disusun untuk mengantisipasi perkembangan masa depan. Titik beratnya, bertujuan untuk mendorong peserta didik atau siswa, agar mampu lebih baik dalam melakukan keterampilan proses. Permendikbud menyatakan bahwa pembelajaran pada jenjang sekolah dasar berdasarkan K-13 mengakomodasi pembelajaran tematik terpadu, keterpaduan lintas mata pelajaran, lintas aspek belajar, dan keragaman budaya (Permendikbud: 65/2013).

Sasaran pembelajaran dalam K-13 mencakup pengembangan ranah sikap, pengetahuan, dan keterampilan yang dielaborasi untuk setiap satuan pendidikan (Permendikbud: 54/2013). Di dalam K-13 dinyatakan juga bahwa penilaian pendidikan sebagai proses pengumpulan dan pengolahan informasi untuk mengukur pencapaian hasil belajar peserta didik mencakup: penilaian otentik, penilaian diri, penilaian berbasis portofolio, ulangan, ulangan harian, ulangan tengah semester, ulangan akhir semester, ujian tingkat kompetensi, ujian mutu tingkat kompetensi, ujian nasional, dan ujian sekolah/madrasah (Permendikbud: 66/2013).

Pada awal diimplementasikannya K-13 telah menuai banyak kontroversi. Penyiapan K-13 dinilai terlalu terburu-buru dan tidak mengacu pada hasil kajian yang sudah matang berdasarkan hasil KTSP dan kurang memperhatikan kesiapan satuan pendidikan dan guru. Padahal kurikulum ini mencakup beberapa perubahan penting baik dari sisi substansi, implementasi, sampai evaluasi. Meskipun demikian, K-13 tetap dilaksanakan secara bertahap mulai tahun pelajaran 2013/2014. Kementerian Pendidikan dan Kebudayaan (Kemendikbud) menjelaskan bahwa pada tahun 2010-2035 adalah bonus demografi bagi Indonesia dalam mempersiapkan generasi emas karena jumlah penduduk dengan usia sekolah sangat tinggi (Tim Penyusun Modul PLPG 2013).

Guru merupakan sumber daya manusia dalam implementasi K-13. Sumber daya manusia yang digunakan akan menentukan implementasi dan keberhasilan kebijakan. Enam variabel yang mempengaruhi proses dan penampilan implementasi yaitu: (1) standar dan tujuan; (2) sumber daya; (3) komunikasi antar organisasi; (4) karakteristik lembaga pelaksana; (5) kondisi sosial, ekonomi, dan politik; dan (6) disposisi pelaksana (Hill dan Hupe, 2009: 46-47). 
LINGUA, Vol. 15, No. 2, September 2018

p ISSN: 1979 9411; e ISSN: 2442 238X

Http://lingua.pusatbahasa.or.id; Email:presslingua@gmail.com

Center of Language and Culture Studies, Surakarta, Indonesia

Susdiana, Emilia Baiq; Hanafi, Nurachman \& Sudirman. 2018. Implementasi Kurikulum 2013 pada Mata Pelajaran Bahasa Indonesia di SMA di Lombok Tengah.

Lingua (2018), 15(2):207 224. DOI:10.30957/lingua.v15i2.527.

K-13 membawa perubahan mendasar peran guru dalam pembelajaran. Secara administratif, pemerintah pusat telah menyiapkan perangkat pelaksanaan pembelajaran yang tidak perlu lagi disiapkan oleh guru. Namun demikian, guru dituntut berperan secara aktif sebagai motivator dan fasilitator pembelajaran sehingga siswa akan menjadi pusat belajar. Hal ini menjadi kendala tersendiri bagi para guru karena tidak semua guru memiliki kompetensi tersebut. Selain itu, guru dituntut kesiapannya untuk melaksanakan kurikulum dalam waktu yang relatif singkat sementara perangkatnya belum disiapkan secara matang.

Kendatipun demikan, faktanya yang terjadi di lapangan dari beberapa SMA Kabupaten Lombok Tengah, meskipun sebagian besar SMA yang ada telah menerapkan intruksi dari pusat melalui Mendikbud untuk mengimplementasikan K-13. Tampaknya terdapat banyak kendala yang ditemui di beberapa sekolah negeri terutama tempat peneliti untuk melakukan penelitian, yakni di SMAN 1 Praya Barat. Sekolah ini telah menggunakan K-13 selama tiga semester. Penerapan K-13 masih terhambat berbagai masalah teknis seperti buku mata pelajaran berbasis $\mathrm{K}-13$ yang belum sepenuhnya diterima pihak sekolah, dan guru yang belum mengerti betul metode pengajaran yang efektif bagi murid didik.

Secara umum terdapat beberapa kendala yang ditemui terkait penerapan K-13 di level SMA, yakni sulitnya mengubah mindset guru, rendahnya moral spiritual, budaya membaca dan meneliti masih rendah, kurangnya penguasaan IT oleh Guru, lemahnya penguasaan bidang administrasi, dan kecenderungan guru yang lebih banyak menekankan aspek kognitif. Padahal semestinya guru juga harus memberikan porsi yang sama pada aspek afektif dan psikomotorik, masih banyak guru yang belum mau menjadi manusia pembelajar, padahal seorang guru dituntut untuk terus menambah pengetahuan dan memperluas wawasannya, terlebih setelah diberlakukannya K-13.

Wawancara awal peneliti di SMAN 1 Praya Barat dengan Kepala Sekolah Saharudin, mengatakan bahwa untuk sekolahnya buku yang tiba baru mencapai $80 \%$ dari total keseluruhan buku yang dibutuhkan. Selain itu, minat baca dari murid rendah dan hanya mempersentasikan tugas dari guru seadanya. Jika disuruh membuka gadget seperti laptop, tablet, ataupun smartphone mereka pasti membuka hal-hal yang justru di luar mata pelajaran. Oleh sebab itu, perlu pengembangan pengawasan lebih lanjut terkait penerapan teknologi pembelajaran ini.

SMAN 1 Praya Barat selalu melakukkan evaluasi setiap semester terhadap hasil $\mathrm{K}-13$. Hasil evaluasi tersebut nantinya akan menjadi point-point yang akan disampaikan ke pendidikan itu sendiri demi kepentingan peserta didik. Intinya K-13 ini menuntut guru lebih kreatif dan inovatif dalam proses pengajaran, seperti biasa hal yang baru akan mendapat penolakan karena sudah nyaman dengan proses pembelajaran yang sudah dilakukan sebelumnya, selain itu masih banyak sekali sekolah yang belum menggunakan K-13 dengan alasan masih belum mampu, terutama sekolah yang berada di daerah. Berdasarkan apa yang telah peneliti paparkan di muka, peneliti mengangkat judul tesis tentang: "Implementasi Kurikulum 2013 pada Pembelajaran Bahasa Indonesia di SMA di Kabupaten Lombok Tengah". Adapun rumusan masalah penelitian ini disusun sebagai berikut: 
LINGUA, Vol. 15, No. 2, September 2018

p ISSN: 1979 9411; e ISSN: 2442 238X

Http://lingua.pusatbahasa.or.id; Email:presslingua@gmail.com

Center of Language and Culture Studies, Surakarta, Indonesia

Susdiana, Emilia Baiq; Hanafi, Nurachman \& Sudirman. 2018. Implementasi Kurikulum 2013 pada Mata Pelajaran Bahasa Indonesia di SMA di Lombok Tengah.

Lingua (2018), 15(2):207 224. DOI:10.30957/lingua.v15i2.527.

- Bagaiamanakah tingkat ketercapaian perencanaan pembelajaran bahasa Indonesia dalam Implementasi K-13 di SMAN 1 Praya Barat Lombok Tengah?

- Bagaimanakah tingkat ketercapaian pelaksanaan pembelajaran bahasa Indonesia dalam implementasi K-13 di SMAN 1 Praya Barat Lombok Tengah?

- Bagaimanakah tingkat ketercapaian penilaian pembelajaran bahasa Indonesia dalam implementasi K-13 di SMAN 1 Praya Barat Lombok Tengah?

\section{TINJAUAN PUSTAKA}

\subsection{Implementasi $\mathrm{K}-13$}

Usman (2002:70) dalam bukunya, Konteks Implementasi Berbasis Kurikulum mengemukakan bahwa implementasi adalah bermuara pada aktivitas, aksi, tindakan, atau adanya mekanisme suatu sistem. Implementasi bukan sekedar aktivitas, tetapi suatu kegiatan yang terencana dan untuk mencapai tujuan kegiatan. Setiawan (2004:39) mengemukakan pendapatnya mengenai implementasi atau pelaksanaan adalah perluasan aktivitas yang saling menyesuaikan proses interaksi antara tujuan dan tindakan untuk mencapainya serta memerlukan jaringan pelaksana, birokrasi yang efektif.

Kajian implementasi K-13 pada pembelajaran bahasa Indonesia di SMA di Kabupaten Lombok Tengah telah dilakukan sebelumnya. Penelitian Siti Maryam (2014) "Penerapan penilaian otentik dalam pembelajaran Bahasa Indonesia" mendeskripsikan penerapan penilaian otentik dalam pembelajaran bahasa Indonesia, yang meliputi model penilaian, langkah-langkah penerapan penilaian otentik, kendalakendala yang dialami guru dalam menerapkan penilaian otentik, dan upaya guru dalam mengatasi kendala dalam penerapan penilaian otentik. Hasil penelitian menunjukkan bahwa semua guru mata pelajaran Bahasa Indonesia telah menerapkan penilaian otentik dalam pembelajaran. Guru menerapkan berbagai macam model penilaian otentik yang menunjukkan bahwa terdapat faktor kreativitas dalam penerapan penilaian.

Maryam (2014) merekomendasikan agar guru mata pelajaran bahasa Indonesia melakukan langkah-langkah penerapan penilaian otentik dengan tepat. Walaupun demikian, guru masih mengalami berbagai macam kendala dalam menerapkan penilaian otentik. Hal ini menunjukkan bahwa guru berusaha menerapkan penilaian otentik dengan baik dan sesuai dengan Kurikulum yang berlaku.

Pardomuan Nauli Josip Mario Sinambela (2013) menulis "Kurikulum 2013 dan implementasinya dalam Pembelajaran." Hasil penelitian menunjukkan bahwa K-13 menuntut agar dalam pelaksanaan pembelajaran siswa diberi kebebasan berpikir memahami masalah, membangun strategi penyelesaian masalah, mengajukan ide-ide secara bebas dan terbuka. Kegiatan guru dalam pembelajaran adalah melatih dan membimbing siswa berpikir kritis dan kreatif dalam menyelesaikan masalah. Guru harus berupaya untuk mengorganisasikan kerjasama dalam kelompok belajar, melatih siswa berkomunikasi menggunakan grafik, diagram, skema, dan variabel. Diharapkan seluruh hasil kerja selalu dipresentasikan di depan kelas untuk menemukan berbagai konsep, hasil penyelesaian masalah, aturan serta prinsip yang ditemukan melalui proses pembelajaran. Pembelajaran tidak hanya ditekankan pada satu aspek saja tetapi keseimbangan pada aspek afektif, aspek psikomotorik, dan aspek kognitif. 
LINGUA, Vol. 15, No. 2, September 2018

p ISSN: 1979 9411; e ISSN: 2442 238X

Http://lingua.pusatbahasa.or.id; Email:presslingua@gmail.com

Center of Language and Culture Studies, Surakarta, Indonesia

Susdiana, Emilia Baiq; Hanafi, Nurachman \& Sudirman. 2018. Implementasi Kurikulum 2013 pada Mata Pelajaran Bahasa Indonesia di SMA di Lombok Tengah.

Lingua (2018), 15(2):207 224. DOI:10.30957/lingua.v15i2.527.

Penelitian Maghfirah Ngabalin (2014) berjudul "Persepsi dan Upaya Guru BI dalam Implementasi Pendekatan Saintifik pada Kurikulum 2013 di SMA Negeri 2 Mataram" bertujuan mengetahui persepsi dan upaya guru bahasa Indonesia dalam implementasi pendekatan saintifik pada K-13 di SMA Negeri 2 Mataram. Hasil penelitian menunjukkan bahwa persepsi dan upaya-upaya yang dilakukan guru bahasa Indonesia dalam implementasi pendekatan saintifik pada K-13 dilakukan melalui sosialisasi K-13, berbagai media, penggunaan sarana dan prasarana sekolah dalam proses pembelajaran bahasa Indonesia dan Budi Pekerti kepada peserta didik.

\subsection{K-13}

\subsubsection{Konsep K-13}

Mulyasa (2014:97-99) menyatakan bahwa Kurikulum 2013 yang berbasis karakter dan kompetensi lahir sebagai jawaban terhadap berbagai kritikan terhadap kurikulum 2006, serta sesuai dengan perkembangan kebutuhan dan dunia kerja. K-13 merupakan salah satu upaya pemerintah untuk mencapai keunggulan masyarakat bangsa dalam penguasaan ilmu dan teknologi seperti yang digariskan dalam haluan negara. Pengembangan K-13 merupakan langkah lanjutan pengembangan Kurikulum Berbasis Kompetensi yang telah dirilis pada tahun 2004 dan KTSP 2006 yang mencakup kompetensi sikap, pengetahuan, dan keterampilan secara terpadu. Tema K-13 adalah menghasilkan insan Indonesia yang produktif, kreatif, inovatif, afektif, melalui penguatan sikap, keterampilan, dan pengetahuan yang terintegrasi. Untuk mewujudkan hal tersebut, dalam implementasi kurikulum, guru dituntut untuk secara professional merancang pembelajaran afektif, dan bermakna (menyenangkan), megorganisasikan pembelajaran, memilih pendekatan pembelajaran yang tepat, menetukan prosedur pembelajaran dan pembentukan kompetensi secara efektif, serta menetapkan kriteria keberhasilan (Mulyasa, 2014:99).

Fadlillah (2014:16) mendefinisikan bahwa K-13 sebagai kurikulum baru yang mulai ditetapkan pada tahun pelajaran 2013/2014. Pada K-13 yang menjadi titik tekan adalah peningkatan dan keseimbangan softskills dan hardskills yang meliputi aspek kompetensi kompetensi sikap, keterampilan, dan pengetahuan. Kemudian, kedudukan kompetensi yang semula yang diturunkan dari mata pelajaran berubah menjadi mata pelajaran dikembangkan dari kompetensi. Selain itu, pembelajaran lebih bersifat tematik integratif dalam semua mata pelajaran. Dalam konteks ini,

K-13 berusaha untuk lebih menanamkan nilai-nilai yang tercermin pada sikap dapat berbanding lurus dengan keterampilan yang diperoleh peserta didik melalui pengetahuan di bangku sekolah. Dengan kata lain, antara softskills dan hardskills dapat tertanam secara seimbang, berdampingan, dan mampu diaplikasikan dalam kehidupan sehari-hari.

\subsubsection{Tujuan K-13}

Poerwati dan Amri (2013:44) menyebutkan bahwa tujuan kurikulum dapat dibagi menjadi empat yaitu tujuan pendidikan nasional, tujuan institusional, tujuan kurikuler, dan tujuan pembelajaran atau instruksional. Berbeda dengan pendapat 
LINGUA, Vol. 15, No. 2, September 2018

p ISSN: 1979 9411; e ISSN: 2442 238X

Http://lingua.pusatbahasa.or.id; Email:presslingua@gmail.com

Center of Language and Culture Studies, Surakarta, Indonesia

Susdiana, Emilia Baiq; Hanafi, Nurachman \& Sudirman. 2018. Implementasi Kurikulum 2013 pada Mata Pelajaran Bahasa Indonesia di SMA di Lombok Tengah.

Lingua (2018), 15(2):207 224. DOI:10.30957/lingua.v15i2.527.

Mulyasa (2014:65) bahwa K-13 bertujuan untuk mempersiapkan insan Indonesia yang produktif, kreatif, inovatif, afektif, melalui penguatan sikap, keterampilan, dan pengetahuan yang terintegrasi. Dalam hal ini, pengembangan kurikulum difokuskan pada pembentukan kompetensi dan karakter peserta didik, berupa panduan pengetahuan, keterampilan, dan sikap yang dapat didemonstrasikan peserta didik sebagi wujud pemahaman terhadap konsep yang dipelajarinya secara kontekstual. K-13 memungkinkan para guru menilai hasil belajar peserta didik dalam proses pencapaian sasaran belajar, yang mencerminkan penguasaan dan pemahaman terhadap apa yang dipelajarinya. Oleh karena itu, peserta didik perlu mengetahui kriteria penguasaan kompetensi dan karakter yang akan dijadikan sebagai standar penilaian hasil belajar, sehingga para peserta didik dapat mempersiapkan dirinya melalui penguasaan terhadap sejumlahkompetensi dan karakter tertentu, sebagai prasyarat untuk melanjutkan ke tingkat penguasaan kompetensi dan karakter berikutnya.

\subsubsection{Karakteristik K-13}

Dalam Permendikbud No. 69 tahun 2013, K-13 dirancang dengan karakteristik sebagai berikut.

a. Mengembangkan keseimbangan antara pengembangan sikap spiritual dan sosial, rasa ingin tahu, kreativitas, kerja sama dengan kemampuan intelektual dan psikomotorik.

b. Sekolah merupakan bagian dari masyarakat yang memberikan pengalaman belajar terencana dimana peserta didik menerapkan apa yang dipelajari di sekolah ke masyarakat dan memanfaatkan masyarakat sebagai sumber belajar.

c. Mengembangkan sikap, pengetahuan, dan keterampilan serta menerapkannya dalam berbagai situasi di sekolah dan masyarakat.

d. Memberi waktu yang cukup leluasa untuk mengembangkan berbagai sikap, pengetahuan, dan keterampilan.

e. Kompetensi dinyatakan dalam bentuk kompetensi inti kelas yang dirinci lebih lanjut dalam kompetensi dasar mata pelajaran.

f. Kompetensi inti kelas menjadi unsur pengorganisasi kompetensi dasar, dimana semua kompetensi dasar dan proses pembelajaran dikembangkan untuk mencapai kompetensi yang dinyatakan dalam kompetensi inti.

g. Kompetensi dasar dikembangkan didasarkan pada prinsip akumulatif, saling memperkuat (reinforced) dan memperkaya (enriched) antar matapelajaran dan jenjang pendidikan (organisasi horizontal dan vertical

\subsubsection{Keunggulan K-13}

Mulyasa (2014:163-164) berpendapat bahwa implementasi K-13 diharapkan dapat menghasilkan insan yang produktif, kreatif, dan inovatif. Hal ini dimungkinkan, karena kurikulum ini berbasis karakter dan kompetensi, yang secara konseptual memiliki keunggulan sebagai berikut.

a. K-13 menggunakan pendekatan yang bersifat alamiah kontekstual), karena berangkat, berfokus, dan bermuara pada hakikat pesertadidik untuk mengembangkan berbagai 
LINGUA, Vol. 15, No. 2, September 2018

p ISSN: 1979 9411; e ISSN: 2442 238X

Http://lingua.pusatbahasa.or.id; Email:presslingua@gmail.com

Center of Language and Culture Studies, Surakarta, Indonesia

Susdiana, Emilia Baiq; Hanafi, Nurachman \& Sudirman. 2018. Implementasi Kurikulum 2013 pada Mata Pelajaran Bahasa Indonesia di SMA di Lombok Tengah.

Lingua (2018), 15(2):207 224. DOI:10.30957/lingua.v15i2.527.

kompetensi sesuai dengan potensinyamasing-masing. Dalam hal ini, peserta didik merupakan subjek belajar, dan proses belajar berlangsung secara alamiah dalam bentuk bekerja dan mengalami berdasarkan kompetensi tertentu, bukan transfer pengetahuan.

b. K-13 yang berbasis karakter dan kompetensi boleh jadi mendasari pengembangan kemampuan-kemampuan lain. Penguasaan ilmu pengetahuan, dan keahlian tertentu dalam suatu pekerjaan, kemampuan memecahkan masalah dalam kehidupan seharihari, serta pengembangan aspek-aspek kepribadian dapat dilakukan secara optimal berdasrkan standar kompetensi tertentu.

c. Ada bidang-bidang studi atau mata pelajaran tertentu yang dalam pengembangannya lebih tepat menggunakan pendekatan kompetensi, terutama yang berkaitan dengan keterampilan

\subsection{Bahasa Indonesia dalam K-13}

\subsubsection{Pengertian Pembelajaran Bahasa Indonesia}

Main (2010:96) berpendapat bahwa mata pelajaran bahasa Indonesia merupakan mata pelajaran yang diajarkan di sekolah sejak sekolah dasar sampai perguruan tinggi. Mata pelajaran bahasa Indonesia merupakan pelajaran yang diajarkan di SD sampai Perguruan Tinggi. Mata pelajaran ini dianggap penting untuk diajarkan di sekolah. BNSP (2006) menjelaskan bahwa bahasa memiliki peran sentral dalam perkembangan intelektual, sosial, dan emosional peserta didik dan merupakan penunjang keberhasilan dalam mempelajari semua bidang studi. Pembelajaran bahasa diharapkan membantu peserta didik mengenal dirinya, budayanya, dan budaya orang lain, gagasan dan perasaan, berpatisipasi dalam masyarakat serta menggunakan kemampuan analitis dan imaginatif yang ada dalam dirinya.

Berbeda dengan pendapat Ngalimun dan Alfulaila (2014:39) mendefinisikan bahwa pembelajaran bahasa Indonesia meliputi komponen-komponen kebahasaan, pemahaman, dan penggunaan. Dalam praktik pembelajaran, guru dapat memusatkan pada salah satu komponen yang ditentukan. Dapat disimpulkan bahwa pembelajaran Bahasa Indonesia adalah pembelajaran yang diajarkan di sekolah sejak sekolah dasar sampai perguruan tinggi yang meliputi komponen-komponen kebahasaan, pemahaman, dan penggunaan.

Pembelajaran bahasa Indonesia diarahkan untuk meningkatkan kemampuan peserta didik untuk berkomunikasi dalam bahasa Indonesia dengan baik dan benar, baik secara lisan maupun tulis, serta menumbuhkan apresiasi terhadap hasil karya kesastraan manusia Indonesia. Rumusan ini menunjukkan bahwa mata pelajaran bahsa Indonesia diselenggarakan untuk meningkatkan kemampuan siswa dalam bersosialisasi dengan sesama dalam berbagai alat komunikasi baik tulis maupun lisan. Di samping itu, penyelenggaraan mata pelajaran bahasa Indonesia juga dimaksudkan agar daya apresiasi sastra siswa terhadap hasil sastra Indonesia tumbuh dengan baik. 
LINGUA, Vol. 15, No. 2, September 2018

p ISSN: 1979 9411; e ISSN: 2442 238X

Http://lingua.pusatbahasa.or.id; Email: presslingua@gmail.com

Center of Language and Culture Studies, Surakarta, Indonesia

Susdiana, Emilia Baiq; Hanafi, Nurachman \& Sudirman. 2018. Implementasi Kurikulum 2013 pada Mata Pelajaran Bahasa Indonesia di SMA di Lombok Tengah.

Lingua (2018), 15(2):207 224. DOI:10.30957/lingua.v15i2.527.

\subsubsection{Tujuan Pembelajaran Bahasa Indonesia}

Main (2010:98) menyebutkan bahwa tujuan mata pelajaran Bahasa Indonesia akan memberi arah seluruh aktivitas pembelajaran. Adapun tujuan mata pelajaran bahasa Indonesia adalah agar peserta didik memiliki kemampuan sebagai berikut.

a. Berkomunikasi secara efektif dan efisien sesuai dengan etika yang berlaku, baik secara lisan maupun tulis.

b. Menghargai dan bangga menggunakan bahasa Indonesia sebagai bahasa persatuan dan bahasa negara.

c. Memahami bahasa Indonesia dan menggunaknnya dengan tepat dan kreatif untuk berbagai tujuan.

d. Menggunakan bahasa Indonesia untuk meningkatkan kemampuan intelektual, serta kematangan emosional dan sosial.

e. Menikmati dan memanfaatkan karya sastra untuk memperluas wawasan, memperhalus budi pekerti, serta meningkatkan pengetahuan dan kemampuan berbahasa.

f. Menghargai dan membanggakan sastra Indonesia sebagai khazanah budaya dan intelektual manusia Indonesia.

\subsubsection{Karakteristik Pembelajaran Bahasa Indonesia K-13}

Mahsun (2014:94) mengemukakan bahwa pada tahun 2013, dalam hal ini Kementrian Pendidikan dan Kebudayaan melakukan suatu perubahan besar dalam ikhtiar mencerdaskan anak bangsa yaitu terkaitan dengan pengembangan Kurikulum. Karakteristik pembelajaran bahasa Indonesia dalam K-13 adalah berbasis pada pembelajaran teks. Suatu keistimewaan dalam K-13 adalah menempatkan bahasa sebagai penghela ilmu pengetahuan. Peran bahasa sebagai penghela ilmu pengetahuan tersebut tentu bukan merupakan suatu kebetulan jika paradigma pembelajaran bahasa Indonesia dalam K-13 diorientasikan pada pembelajaran berbasis teks, seperti dilihat dalam rumusan kompetensi dasar subtansi bahasa Indonesia dari pendidikan dasar sampai pendidikan tinggi. Hanya saja bedanya, jenis teks yang diajarkan pada pendidikan dasar sampai pendidikan menengah adalah teks langsung (kontinu) atau teks-teks tunggal atau genre mikro, sedangkan jenis teks yang diajarkan pada perguruan tinggi adalah jenis teks tidak langsung (diskontinu) atau teks-teks majemuk atau genre makro. Oleh karena itu, penempatan bahasa Indonesia sebagai penghela ilmu pengetahuan dalam K-13 memberi harapan baru bagi tumbuhnya keyakinan bangsa ini pada kebesaran apa yang menjadi lambang identitas kebangsaanya, yaitu bahasa Indonesia. Perancangan pembelajaran bahasaIndonesia berbasis teks selain keutamaan seperti disebutkan di atas, juga memberi ruang pada peserta didik ntuk mengembangkan berbagai jenis struktur berpikir, karena setiap teks memiliki struktur berpikir yang berbeda satu sama lain. Semakin banyak jenis teks yang dikuasai, maka semakin banyak struktur beripikir yang dikuasai peserta didik (Mahsun, 2014:95). 
LINGUA, Vol. 15, No. 2, September 2018

p ISSN: 1979 9411; e ISSN: 2442 238X

Http://lingua.pusatbahasa.or.id; Email: presslingua@gmail.com

Center of Language and Culture Studies, Surakarta, Indonesia

Susdiana, Emilia Baiq; Hanafi, Nurachman \& Sudirman. 2018. Implementasi Kurikulum 2013 pada Mata Pelajaran Bahasa Indonesia di SMA di Lombok Tengah.

Lingua (2018), 15(2):207 224. DOI:10.30957/lingua.v15i2.527.

\subsubsection{Perubahan Pembelajaran Bahasa Indonesia dalam K-13}

Mahsun (2014:95) menjelaskan bahwa terdapat perubahan mendasar dalam K13, khususnya bidang pembelajaran bahasa Indonesia. Perubahan dimaksud terjadi pada paradigma penetapan satuan kebahasaan yang menjadi basis materi pembelajaran. Perubahan pada materi tersebut, membawa dampak pada perubahan metode pembelajaran. Adapun satuan bahasa yang menjadi basis pembelajarannya adalah teks. Jadi, pembelajaran bahasa dengan mempertimbangkan konteks situasi pemakaian bahasa itu sendiri. Beberapa pakar bahasa, yang terlibat dalam pengembangan kurikulum sebelumnya, Kurikulum 1994, 2004, dan 2006, menyatakan bahwa pembelajaran bahasa yang mempertimbangkan konteks situasi pemakaian bahasa sesungguhnya sudah mulai dari kurikulum 1994 dan diperkuat kembali melalui kurikulum 2004 dan 2006.

Semua jenis teks pada KTSP berstruktur tunggal yaitu pembuka, isi, dan penutup. Dengan demikian, rumusan kompetensi dasar pada KTSP, masih mencampuradukkan antara pendekatan liguistik struktural dengan linguistik sistemik fungsional. Suatu hal yang sangat berbeda dengan K-13 yang sepenuhnya berbasis teks lainnya berbeda, karena fungsi sosial yang diemban setiap teks berbeda. Dengan kata lain, K-13 sepenuhnya mendasarkan diri pada pendekatan linguistik sistemik fungsional. Persoalan mengenai teks dijadikan basis dalam pembelajaran K-13, ada beberapa alasan yang dapat dikemukakan untuk hal tersebut. Pertama, melalui teks kemampuan berpikir siswa dapat dikembangkan. Kedua, materi pembelajaran berupa teks lebih relevan dengan karakteristik K-13 yang menetapkan capaian kompetensi siswa yang mencakupi ketiga ranah pendidikan, pengetahuan, keterampilan, dan sikap (Mahsun, 2014:97).

\subsubsection{Implementasi K-13 dalam Pembelajaran Bahasa Indonesia}

Kamus Besar Bahasa Indonesia, implementasi adalah pelaksanaan dan penerapan dimana kedua hal ini bermaksud untuk mencari bentuk tentang hal yang disepakati terlebih dahulu. Implementasi adalah proses untuk memastikan terlaksananya suatu kebijakan dan tercapainya kebijakan tersebut. Implementasi juga dimaksudkan menyediakan sarana untuk membuat sesuatu yang memberikan hasil yang bersifat praktis terhadap sesama. Hamalik (2009:237) implementasi merupakan suatu proses penerapan ide, konsep, kebijakan, atau inovasi dalam bentuk tindakan praktis sehingga memberikan dampak, baik berupa perubahan pengetahuan, keterampilan, maupun nilai dan sikap. Berdasarkan beberapa definisi mengenai implementasi di atas dapat disimpulkan bahwa implementasi adalah pelaksanaan dan penerapan ide, konsep, kebijakan atau inovasi untuk memastikan terlaksananya suatu kebijakan tersebut dengan memberikan hasil yang bersifat praktis.

Mulyasa (2014:99) mendefinisikan bahwa implementasi K-2013 merupakan aktualisasi kurikulum dalam pembelajaran dan pembentukkan kompetensi serta karakter peserta didik. Hal tersebut menuntut keaktifan guru dalam menciptakan dan menumbuhkan berbagai kegiatan sesuai dengan rencana yang telah diprogramkan. K-13 atau pendidikan berbasis karakter adalah kurikulum baru yang dicetuskan oleh 
LINGUA, Vol. 15, No. 2, September 2018

p ISSN: 1979 9411; e ISSN: 2442 238X

Http://lingua.pusatbahasa.or.id; Email:presslingua@gmail.com

Center of Language and Culture Studies, Surakarta, Indonesia

Susdiana, Emilia Baiq; Hanafi, Nurachman \& Sudirman. 2018. Implementasi Kurikulum 2013 pada Mata Pelajaran Bahasa Indonesia di SMA di Lombok Tengah.

Lingua (2018), 15(2):207 224. DOI:10.30957/lingua.v15i2.527.

Kementrian Pendidikan dan Kebudayaan RI sebagai pengganti KTSP. K-13 merupakan tindak lanjut dari KBK. Revitalisasi dan penekanan pendidikan karakter dalam pengembangan K-13, diharapkan dapat menyiapkan SDM yang berkualitas, sehingga, masyarakat dan bangsa Indonesia bisa menjawab berbagai masalah dan tantangan yang semakin rumit dan kompleks. Implementasi K-13 menuntut kerjasama yang optimal di antara para guru, sehingga memerlukan pembelajaran berbentuk tim, dan menuntut kerjasama yang kompak di antara para anggota tim.

Kerjasama antara para guru sangat penting dalam proses pendidikan yang akhirakhir ini mengalami perubahan yang sangat pesat (Mulyasa, 2014:9). Implementasi K13 akan dilaksanakan secara terbatas dan bertahap mulai tahun ajaran 2013/2014 yaitu Juli 2013. K-13 diterapkan di sekoalah yang menjadi pilot project atau sekolah percontohan dan terdapat pada beberapa sekolah unggulan atau favorit yang dipandang siap untuk menginmplementasikan K-13. Implementasi K-13 dalam pembelajaran Bahasa Indonesia meliputi tiga aspek yaitu perencanaan pembelajaran, pelaksanaan pembelajaran, dan penilaian proses pembelajaran.

\section{METODE}

\subsection{Desain Penelitian}

Penelitian ini merupakan penelitian survei yang bertujuan untuk mendeskripsikan implementasi K-13 dalam pembelajaran bahasa Indonesia di SMA Negeri I Praya Barat. Penelitian survei merupakan penelitian non-hipotesis tetapi ditekankan pada pengumpulan data yang objektif dan memberikan kesimpulan berdasarkan kriteria penelitian. Berdasarkan tujuan penelitian tersebut, maka desain penelitian yang dipilih adalah cross-sectional survey, yakni penelitian yang dilakukan pada satu waktu tertentu dan tidak mencari hubungan antar variabel atau tidak untuk mengetahui perubahan individu yang menjadi anggota sampel. Penelitian survei dilakukan untuk mengukur tingkat ketercapaian perencanaan, pelaksanaan, dan penilaian pembelajaran bahasa Indonesia dalam implementasi K-13 di SMAN 1 Praya Barat.

\subsection{Subjek Penelitian}

Populasi dalam penelitian ini adalah semua guru dan siswa di SMA Negeri I Praya Barat yang menerapkan Kurikulum 2013. Sampel yang diambil dari populasi harus betul-betul representatif. Di SMA Negeri 1 Praya Barat, K-13 diterapkan untuk siswa kelas X dan XI, kelas XII masih menerapkan KTSP. Sampel dalam penelitian ini adalah empat orang guru mata pelajaran Bahasa Indonesia yang menerapkan K-13. Untuk sampel siswa dipilih siswa kelas XI yang telah menerapkan K-13 selama tiga semester.

\subsection{Instrumen Penelitian}

Pengertian instrumen penelitian menurut (Suharsimi Arikunto, 2006:160) adalah alat atau fasilitas yang digunakan oleh peneliti dalam mengumpulkan data, agar pekerjaannya lebih mudah dan hasilnya lebih baik dalam arti lebih cermat, lengkap dan 
sistematis. Sesuai dengan metode pengumpulan data yang dipilih, penelitian ini menggunakan instrumen berupa pedoman observasi dan pedoman wawancara.

\section{a. Pedoman Observasi}

Pedoman observasi digunakan agar peneliti dapat melakukkan pengamatan sesusai dengan tujuan penelitian. Pedoman observasi dalam penelitian ini digunakan untuk mengetahui program perencanaan pembelajaran yang telah disusun oleh guru kelas.

\section{b. Pedoman Wawancara}

Pedoman wawancara digunakan agar wawancara yang dilakukan tidak meyimpang dari tujuan penelitian. Pedoman ini disusun tidak hanya berdasarkan teori yang berkaitan dengan masalah yang diteliti. Pedoman wawancara dalam penelitian ini digunakan untuk mengetahui keompetensi guru dalam perencanaan pembelajaran.

\section{c. Angket siswa}

Angket untuk mengumpulkan data dengan fokus permasalahan mengenai pelaksanaan pembelajaran diberikan kepada siswa. Pemilihan siswa sebagai responden dalam pengambilan data, karena siswa dianggap tahu keadaan sebenarnya di lapangan dan siswa terlibat langsung dalam proses pembelajaran.

Angket ini berisi pertanyaan yang berkaitan dengan pelaksanaan pembelajaran Bahasa Indonesia. Instrumen angket menggunakan teknik skala likert. Prinsip pokok skala likert adalah menentukan lokasi kedudukan seseorang dalam suatu kontinu sikap terhadap objek sikap, mulai dari sangat negatif sampai sangat positif. Angket ini bersifat tertutup karena responden sudah diberikan pilihan jawaban yang terdiri dari (1) Selalu, (2) Sering, (3) Jarang, (4) Tidak Pernah. Responden dapat memilih salah satu jawaban yang dirasa tepat.

Menurut Sugiyono (2013:136) skala likert menggunakan 5 skala yang dimodifikasi menjadi limaalternatif jawaban yaitu Sangat setuju (SS), setuju (S), tidak tahu (TT), tidak Setuju (TS) dan sangat tidak setuju (STS) dengan menghilangkan alternatif jawaban $\mathrm{R}$ (Ragu-Ragu) karena kebanyakaan orang mengambil alur tengah atau memilih alternatif tersebut dan tidak memiliki jawaban yang ekstrim.

Tabel 1. Skala Pengukuran Likert

\begin{tabular}{|c|c|c|c|}
\hline No & Pilih respon & Singkatan & Skor \\
\hline $\mathbf{1 .}$ & Sangat setuju & SS & 5 \\
\hline $\mathbf{2 .}$ & Setuju & S & 4 \\
\hline $\mathbf{3 .}$ & Tidak tahu & TT & 3 \\
\hline $\mathbf{4 .}$ & Tidak setuju & TS & \\
\hline $\mathbf{5 .}$ & Sangat tidak setuju & STS & 1 \\
\hline
\end{tabular}

(Sugiyono, 2013: 136) 
LINGUA, Vol. 15, No. 2, September 2018

p ISSN: 1979 9411; e ISSN: 2442 238X

Http://lingua.pusatbahasa.or.id; Email: presslingua@gmail.com

Center of Language and Culture Studies, Surakarta, Indonesia

Susdiana, Emilia Baiq; Hanafi, Nurachman \& Sudirman. 2018. Implementasi Kurikulum 2013 pada Mata Pelajaran Bahasa Indonesia di SMA di Lombok Tengah.

Lingua (2018), 15(2):207 224. DOI:10.30957/lingua.v15i2.527.

\section{d. Angket Guru}

Angket yang berisi pertanyaan guna mengumpulkan data yang berkaitandengan perencanaaan pembelajaran, pelaksanaan pembelajaran, dan penilaian pembelajaran diberikan kepada guru. Angket ini bersifat tertutup karena responden sudah diberikan pilihan jawaban yang terdiri dari (1) Sangat setuju, (2) Setuju, (3) tidak tahu, (4) tidak setuju, (5) sangat tidak setuju. Responden dapat memilih salah satu jawaban yang dirasa tepat.

\subsection{Teknik analisis data}

Teknik analisis data dalam penelitian ini menggunakan metode analisis deskriptif kuantitatif dan kualitatif. Deskriptif kuantitatif merupakan statistik yang bertujuan untuk menganalisis data dengan cara mendeskripsikan atau menggambarkan data yang diperoleh sesuai fakta dan apa adanya tanpa bertujuan untuk membuat kesimpulan yang berlaku umum. Data diperoleh dari angket, wawancara, dan dokumentasi. Dari data angket dianalisis dengan cara kuantitatif. Data yang diperoleh dari wawancara dan dokumentasi dianalisis dengan cara kualitatif. Sebelum dianalisis, dilakukan proses kuantifikasi data dari angket. Setelah dilakukan kuantifikasi, selanjutnya data tersebut dianalisis dengan menggunakan statistik deskriptif. Data hasil wawancara dianalisis dengan analisis kualitatif.

\section{HASIL DAN BAHASAN}

\subsection{Kendala Implementasi K-13}

\section{a. Keterbatasan Waktu}

Pelaksanaan pembelajaran juga terkendala keterbatasan waktu. Mata pelajaran Bahasa Indonesia dalam satu minggu menjadi 4 jam pelajaran. Di Kabupeten Lombok Tengah, ada yang langsung 4 jam dalam satu pertemuan dan ada yang dibuat menjadi 2 x 2 jam dalam seminggu. Hal ini menyesuaikan keadaan sekolah masing-masing dan menyesuaikan jadwal dengan mata pelajaran lain. Jika dibuat 4 jam langsung pada satu pertemuan, materi bisa disampaikan langsung hingga selesai namun terkendala peserta didik akan merasa bosan karena terlalu lama. Jika dibuat $2 \times 2$ jam, biasanya pertemuan pertama hanya sampai pada tahap menalar, kemudian sisanya diteruskan pada pertemuan selanjutnya.

\section{b. Keterbatasan Sarana dan Prasarana}

Sagala (2003) menegaskan kebermaknaan pembelajaran sangat ditunjang oleh sarana dan prasarana yang melengkapinya. Berdasarkan hasil wawancara, buku siswa pada cetakan pertama masih kurang sempurna dan sangat perlu direvisi. Kekurangan buku siswa tersebut bisa dilihat dari konten bukunya maupun tanda baca atau kesalahan penulisan. Materi di dalam buku tidak urut sesuai dengan silabus dan ada materi yang belum ada. Ketidaksesuaian materi membuat guru harus menyesuaikan antara buku dan silabus serta melengkapi materi sendiri. Buku kurang menjelaskan materi, sehingga guru perlu mencarikan tambahan materi agar pengetahuan peserta didik lebih lengkap. 
LINGUA, Vol. 15, No. 2, September 2018

p ISSN: 1979 9411; e ISSN: 2442 238X

Http://lingua.pusatbahasa.or.id; Email:presslingua@gmail.com

Center of Language and Culture Studies, Surakarta, Indonesia

Susdiana, Emilia Baiq; Hanafi, Nurachman \& Sudirman. 2018. Implementasi Kurikulum 2013 pada Mata Pelajaran Bahasa Indonesia di SMA di Lombok Tengah.

Lingua (2018), 15(2):207 224. DOI:10.30957/lingua.v15i2.527.

\section{c. Kendala Penilaian}

Pada semester ketiga implementasi K-13, guru mengatakan bahwa penilaian proyek belum dilaksanakan. Namun, untuk pelaksanaan pada tahun pertama sudah dilaksanakan. Penilaian yang sudah dilaksanakan di keenam sekolah tersebut biasanya adalah penilaian diri, penilaian teman sejawat, penilaian portofolio, penilaian tertulis, jurnal oleh beberapa guru, dan observasi. Sedangkan penilaian lain akan dilaksanakan seiring berjalannya waktu. Kesulitan dalam penilaian yang dirasakan adalah ketika proses pemberian materi, guru juga harus menilai perilaku siswa. Berkaitan dengan hal tersebut guru merasa kurang fokus. Banyaknya jenis penilaian membuat guru merasa bingung menentukan waktu pelaksanaan penilaian. Sementara guru masih memiliki tugas lain yang harus dipenuhi, namun juga harus melaksanakan berbagai jenis penilaian. Hal ini mengakibatkan belum terlaksananya semua penilaian dan berkaitan dengan keterbatasan waktu.

\section{d. Kendala Kreativityas Peserta Didik dalam Proses Belajar Mengajar}

Berdasarkan wawancara, salah satu guru mengungkapkan bahwa peserta didik di sekolahnya sudah aktif secara keseluruhan. Namun, pada sekolah lainnya kreaktitas peserta didik belum merata. Berdasarkan hasil wawancara, ada kelas yang memiliki peserta didik aktif hanya di kelas tertentu. Ada juga hanya ada beberapa anak aktif dalam satu kelas, dan sisanya masih tergolong pasif. Hal ini dipengaruhi oleh perbedaan individu masing-masing peserta didik. Peserta didik yang tergolong pasif adalah peserta didik yang pendiam, pemalu atau kurang percaya diri. Peserta didik ini tidak terbiasa berbicara di muka umum.

\subsection{Mengahadapi Kendala Pembelajaran Bahasa Indonesia dalam K-13 a. Upaya Mengatasi Kendala Keterbatasan Waktu}

Keterbatasan waktu yang dialami guru berupa keterbatasan waktu dalam menyelesaikan administrasi guru, perencanaan pembelajaran, proses pembelajaran, dan penilaian. Upaya yang dilakukan guru untuk mengatasi kendala tersebut adalah: (1) Administrasi merupakan tugas masing-masing guru. Administrasi guru dapat berupa RPP, Program Tahunan, Program Semester, Rubrik Penilaian, Pedoman Penilaian, Analisis, SK/KD, dll.

Banyak administrasi guru yang perlu dibuat, guru mengatasi dengan menyelesaikan di rumah, (2) Pembuatan RPP juga dilaksanakan di rumah dengan mengorbankan waktu bersama keluarga atau mengurangi waktu istrirahat di rumah. Hal ini dilakukan karena tidak memungkinkan pembuatan RPP dilaksanakan di sekolah, (3) Keterbatasan waktu dalam proses pembelajaran, guru melakukan upaya dengan penugasan atau pengerjaan soal. Satu pertemuan guru mengusahakan pemberian materi selesai dan tujuan pembelajaran tercapai.

Jika karena alasan tertentu tujuan belum tercapai, guru akan melanjutkan pada pertemuan selanjutnya, (4) Upaya guru dalam mengatasai keterbatasan waktu dalam penilaian dilakukan dengan melihat kondisi dan situasi yang ada di dalam kelas. Jika tidak memungkinkan memberikan penilaian secara individu, guru akan melakukan 
LINGUA, Vol. 15, No. 2, September 2018

p ISSN: 1979 9411; e ISSN: 2442 238X

Http://lingua.pusatbahasa.or.id; Email:presslingua@gmail.com

Center of Language and Culture Studies, Surakarta, Indonesia

Susdiana, Emilia Baiq; Hanafi, Nurachman \& Sudirman. 2018. Implementasi Kurikulum 2013 pada Mata Pelajaran Bahasa Indonesia di SMA di Lombok Tengah.

Lingua (2018), 15(2):207 224. DOI:10.30957/lingua.v15i2.527.

penilaian kelompok yang biasanya berupa penilaian proyek. Upaya yang lain juga ketika tidak waktu terbatas memberikan penilaian di dalam kelas, guru akan memberikan penilaian di luar kelas (observasi atau jurnal).

Menjadi sumber belajar yang penting. Sekolah dengan sarana internet kurang bagus, guru akan mengatasi dengan memperbolehkan peserta didik menggunakan handphone untuk keperluan browsing materi. Sementara untuk keterlambatan buku, ada guru yang memberikan hasil print dan ada yang memberikan softfile. Namun, penggunaan softfile dianggap kurang nyaman nyaman dilakukan dalam pembelajaran.

\section{b. Upaya Mengatasi Kendala Penilaian}

Melalui wawancara diketahui bahwa guru mengalami kesulitan dalam pembuatan rubrik penialaian. Guru mengatasi hal tersebut dengan membahas dan membuat pedoman rubrik penilaian yang kemudian dapat digunakan bersama. Sebelumnya, guru juga membaca berbagai buku mengenai penilaian untuk menambah pengetahuan mengenai penilaian yang perlu dilakukan. Guru mengatasi kendala penilaian dengan upaya membuat rencana dan gambaran yang sesuai dengan keadaan peserta didik.

Banyaknya jenis penilaian dalam Kurikulum 2013 di atasi dengan melakukan penilaian satu persatu dan melihat kondisi penilaian yang memungkinkan dilaksanakan terlebih dahulu. Melalui hasil wawancara, penilaian diri dan teman sejawat dilaksanakan sebelum tes tertulis. Guru mengatasi penilaian portofolio yang sulit dilaksanakan dengan memberikan tugas kepada peserta didik dan dikumpulkan menjadi satu buku tugas.

Beberapa sekolah melakukan penilaian proyek dengan penugasan kelompok dan dikerjakan di luar jam pelajaran. Upaya-upaya tersebut sudah dilakukan guru secara maksimal guna mengimplementasikan Kurikulum 2013 sesuai dengan harapan dan idealnya. Kendala lain yang belum bisa diatasi, masih dalam proses menemukan upaya dan solusi yang tepat dengan kendala yang dialami.

\subsection{Mengatasi Kendala Keaktivan Peserta Didik dalam Poses Belajar Mengajar}

Guru mengatasi keterbatasan peserta didik dengan memberikan motivasi kepada peserta didik yang masih pasif. Motivasi bertujuan untuk menambah kepercayaan diri peserta didik. Berdasarkan hasil wawancara guru mengatakan perlu memberikan rangsangan-rangsangan atau pancingan kepada peserta didik yang pendiam dan pemalu untuk berani berbicara di depan kelas. Guru juga mengungkapkan memberikan pujian atau memberikan tambahan nilai bagi peserta didik aktif dalam pembelajaran. Guru mengaku bahwa tidak mudah membuat peserta didik tersebut bersedia mengekspresikan diri di depan kelas.

Guru juga melakukan upaya dengan memilih dan menggunakan metode yang tepat. Hasil wawancara diperoleh data bahwa metode yang paling sering digunakan adalah metode diskusi. Metode diskusi dianggap sesuai untuk mengatasi peserta didik yang pasif. Peserta didik diharapkan ikut serta aktif dalam diskusi beserta kelompok, 
LINGUA, Vol. 15, No. 2, September 2018

p ISSN: 1979 9411; e ISSN: 2442 238X

Http://lingua.pusatbahasa.or.id; Email:presslingua@gmail.com

Center of Language and Culture Studies, Surakarta, Indonesia

Susdiana, Emilia Baiq; Hanafi, Nurachman \& Sudirman. 2018. Implementasi Kurikulum 2013 pada Mata Pelajaran Bahasa Indonesia di SMA di Lombok Tengah.

Lingua (2018), 15(2):207 224. DOI:10.30957/lingua.v15i2.527.

aktif mencari data dan belajar mandiri, dan berani menyampaikan hasil diskusi di depan kelas.

Diskusi kelompok juga dianggap sebagai ruang untuk berekspresi, karena berdiskusi bersama teman bertujuan agar setiap anak tidak merasa canggung. Presentasi digunakan guru sebagai tempat bagi peserta didik untuk mengekspresikan hasil pekerjaan dalam diskusi.

\subsection{Implementasi K-13}

Di Kabupeten Lombok Tengah ada enam sekolah menengah negeri yang mengimplementasikan Kurikulum 2013 sejak tahun pertama (2013/2014). Sekolahsekolah tersebut merupakan pionir atau sekolah sasaran sebagai uji coba implementasi Kurikulum 2013. Dari data wawancara, diketahui secara pasti bahwa keenam sekolah tersebut memang sebagai sekolah sasaran Kurikulum 2013. Pada tahun pertama implementasi dilaksanakan pada kelas XI, kemudian implementasi tahun kedua mulai dilaksanakan pada kelas XI dan XII setiap sekolah.

Guru-guru yang mengimlementasikan pada awalnya melewati diklat terlebih dahulu. Implementasi Kurikulum 2013 pada tahun pertama dilaksanakan difokuskan pada guru yang mengajar kelas XI. Setelah kelas XI mendapat diklat, kemudian diklat diberikan dahulu secara bergantian. Beberapa guru ketika diwawancarai bahwa diklat kurang membantu. Diklat yang didapatkan memberikan gambaran secara jelas dan rinci mengenai implementasi Kurikulum 2013. Beberapa guru merasa pengimplementasian Kurikulum 2013 sangat dipaksakan.

Pemahaman guru mengenai Kurikulum 2013 memang sangat penting. Kurikulum 2013 dalam proses pembelajaran diterapkan oleh guru, jika pemahaman mengenai Kurikulum 2013 belum baik, bagaimana guru dapat mengimplementasikan dengan baik. Implementasi Kurikulum 2013 di Kabupaten Lombok Tengah dapat diketahui dari komponen sebagai berikut.

\section{a. Rencana Pelaksanaan Pembelajaran}

Menurut David (2010) dijelaskan salah satu komponen terpenting dalam pelaksanaan pembelajaraan adalah desain. Desain pembelajaran yang dimaksud di sini adalah Rancangan Pembelajaran. Berdasarkan hasil wawancara guru mengatakan bahwa RPP 2013 mengalami perubahan jika dibandingkan dengan RPP kurikulum sebelumnya. Akan tetapi, konten dan garis besar dari RPP antara Kurikulum 2013 dengan KTSP tetap sama. Dari hasil wawancara, guru menuturkan bahwa guru menyiapkan RPP sendiri yang diturunkan berdasarkan silabus.

Adapun untuk bentuk atau format RPP, beberapa guru menggunakan format yang disetujui forum MGMP Bahasa Indonesia Lombok Tengah dan beberapa guru menggunakan format dari dinas. Namun, antara format MGMP dengan format dinas memunyai ketidakseragaman. Hal tersebut menimbulkan kebingungan bagi guru. Guruguru menyatakan sebaiknya ada keseragaman antara MGMP dan dinas, sehingga guru menggunakan satu format RPP saja. 
LINGUA, Vol. 15, No. 2, September 2018

p ISSN: 1979 9411; e ISSN: 2442 238X

Http://lingua.pusatbahasa.or.id; Email:presslingua@gmail.com

Center of Language and Culture Studies, Surakarta, Indonesia

Susdiana, Emilia Baiq; Hanafi, Nurachman \& Sudirman. 2018. Implementasi Kurikulum 2013 pada Mata Pelajaran Bahasa Indonesia di SMA di Lombok Tengah.

Lingua (2018), 15(2):207 224. DOI:10.30957/lingua.v15i2.527.

\section{b. Pendekatan Saintifik}

Berdasarkan wawancara, guru mengatakan bahwa sebenarnya pendekatan saintifik sudah dilaksanakan sejak KTSP. Hanya saja pada kurikulum sebelumnya tidak dikenal dengan istilah pendekatan saintifik. Kegiatan mengamati, menanya, menalar, mengasosiasikan, dan mengomunikasikan sebenarnya sudah diterapkan. Hal tersebut sesuai dengan penjelasan dalam Materi Pelatihan Guru Implementasi Kurikulum 2013 dalam Modul Pelatihan Implementasi Kurikulum 2013 (Kemendikbud, 2013: 194-207) meskipun dalam pelaksanaannya belum terorganisasi.

Guru berpendapat jika langkah pendekatan saintifik belum dapat dilaksanakan semua tidak menjadi masalah. Bagi guru yang terpenting adalah tujuan pembelajaran tercapai dan materi dapat dipahami dengan baik oleh peserta didik. Keaktifan peserta didik dalam proses pembelajaran belum menyeluruh. Belum semua peserta didik aktif dalam pembelajaran. Salah satu guru mengatakan bahwa peserta didik aktif, karena memang dituntut untuk aktif. Peserta didik harus dapat mengimbangi dan menyesuaikan proses pembelajaran sesuai dengan Kurikulum 2013.

\section{c. Metode Pembelajaran}

Guru juga menggunakan metode lain yang dirasa cocok dan tepat pada peserta didik untuk materi tertentu. Kurikulum 2013 juga menganjurkan pembelajaran tidak hanya dilaksanakan di dalam kelas, pembelajaran bisa dilakukan di luar kelas. Berdasarkan hal tersebut, beberapa guru mengungkapkan sudah melaksanakan pembelajaran di luar kelas. Namun, sebagian besar guru mengungkapkan untuk sementara waktu masih melaksanakan pembelajaran di dalam kelas. Guru yang sudah melaksanakan pembelajaran di luar kelas berpendapat bahwa hal tersebut dilakukan untuk mengatasi rasa bosan peserta didik jika melakukan pembelajaran di dalam kelas secara terus-menerus.

\section{d. Media Pembelajaran}

Berdasarkan hasil wawancara, media yang paling sering digunakan guru adalah LCD proyektor, audio-visual, dan teks pendukung. Semua sekolah memang sudah menyediakan LCD di tiap kelas. Media tambahan lain juga digunakan guru, seperti buku, koran, majalah, alat peraga, lingkungan sekitar, ataupun internet. Seiring perkembangan zaman, internet merupakan fasilitas yang sangat diperlukan. Pemilihan media tersebut dilakukan guru menyesuaikan materi yang diajarkan agar peserta didik dapat memahami materi dengan baik.

\section{SIMPULAN}

Hasil dan bahasan penelitian ini menunjukkan bahwa terdapat capaian dan kendala pelaksanaan pembelajaran bahasa Indonesia berdasarkan K-13 di SMA di Lombok Tengah. Hasil penelitian dapat disimpulkan bahwa:

1) Guru kelas XII mata pelajaran bahasa Indonesia SMA Negeri 1 Praya Barat Kabupaten Lombok Tengah mengimplementasikan K-13 dalam pembelajaran berupa: a) penyusunan RPP berdasarkan silabus yang disiapkan pemerintah 
LINGUA, Vol. 15, No. 2, September 2018

p ISSN: 1979 9411; e ISSN: 2442 238X

Http://lingua.pusatbahasa.or.id; Email: presslingua@gmail.com

Center of Language and Culture Studies, Surakarta, Indonesia

Susdiana, Emilia Baiq; Hanafi, Nurachman \& Sudirman. 2018. Implementasi Kurikulum 2013 pada Mata Pelajaran Bahasa Indonesia di SMA di Lombok Tengah.

Lingua (2018), 15(2):207 224. DOI:10.30957/lingua.v15i2.527.

menggunakan format MGMP Bahasa Indonesia Kabupaten Lombok Tengah atau format dinas, b) penggunaan pendekatan saintifik dalam proses pembelajaran, c) penggunaan metode yang sering diterapkan adalah diskusi, tanya jawab, dan penugasan yang terangkum dalam pendekatan saintifik, d) penggunaan media LCD proyektor, audio-visual, dan teks pendukung dalam proses belajar, e) sumber belajar berupa buku wajib dari pemerintah, buku dari penerbit lain sebagai referensi, dan internet, f) penggunaan penilaian sesuai K-13.

2) Tanggapan guru Guru kelas XII mata pelajaran bahasa Indonesia SMA Negeri 1 Praya Barat Kabupaten Lombok Tengah terhadap K-13 merupakan kurikulum yang bagus dan ideal, peserta didik lebih aktif dan mandiri dalam belajar. Namun, dalam implementasi masih membutuhkan penyempurnaan dan waktu implementasi terkesan mendadak. Beberapa guru mengungkapkan lebih merasa nyaman dengan KTSP.

3) Implementasi K-13 masih mengalami banyak kendala. Kendala tersebut adalah keterbatasan waktu, keterbatasan sarana dan prasarana, penilaian, dan keaktifan peserta didik dalam proses belajar mengajar. Guru kelas XII mata pelajaran Bahasa Indonesia SMA Negeri 1 Praya Barat Kabupaten Lombok Tengah mengatasi kendala implementasi K-13 dengan upaya sebagai berikut: a) untuk mengatasi keterbatasan waktu guru memberikan tugas rumah, mengadakan penilaian secara kelompok dan menyelesaikan administrasi guru di rumah. b) untuk mengatasi kendala keterbatasan sarana dan prasarana guru menggunakan media yang tersedia dan berusaha melengkapi sarana dan prasarana secara mandiri. c) untuk mengatasi kesulitan menerapkan penilaian dengan melihat kondisi penilaian yang memungkinkan segera dilaksanakan, melakukan penilaian di luar kelas, memberikan tugas kelompok jika tidak memungkinkan dilakukan penilaian individu.

\section{DAFTAR PUSTAKA}

Bintari, Ni Luh Gede Riwan Putri, I Nyoman Sudiana, Ida Bagus Putrayasa, 2014, "Pembelajaran Bahasa Indonesia Ber dasarkan Pendekatan Saintifik (Problem Based Learning) Sesuai Kurikulum 2013 Di Kelas VII SMP Negeri 2 Amlapura”. E-Journal, Vol 3.

David A. Walczak, 2010, A Program for Introducing Information Literacy to Commercial Art and Design, Students Communications in Information Literacy, Volume (2).

Departemen Pendidikan Nasional, 2005, Undang-undang Republik Indonesia Nomor 14 tahun 2005 tentang Guru dan Dosen, Jakarta: Departemen Pendidikan Nasional.

Kementrian Pendidikan dan Kebudayaan, 2012, "Pengembangan Kurikulum 2013" disampaikan dalam sosialisasi Kurikulum 2013 di Jember pada 25 Agustus 2013.

Kurinasih, Imas dan Berlin Sani (B), 2014, Sukses Mengimplementasikan Kurikulum 2013: Memahami Berbagai Aspek dalam Kurikulum 2013. Surabaya: Kata Pena.

Maryam, Siti, 2013, "Penerapan Penilaian Otentik dalam Pembelajaran Bahasa Indonesia di SMP se-Kecamatan Wates", Skripsi S1 Yogyakarta: Universitas Negeri Yogyakarta. 
LINGUA, Vol. 15, No. 2, September 2018

p ISSN: 1979 9411; e ISSN: 2442 238X

Http://lingua.pusatbahasa.or.id; Email: presslingua@gmail.com

Center of Language and Culture Studies, Surakarta, Indonesia

Susdiana, Emilia Baiq; Hanafi, Nurachman \& Sudirman. 2018. Implementasi Kurikulum 2013 pada Mata Pelajaran Bahasa Indonesia di SMA di Lombok Tengah.

Lingua (2018), 15(2):207 224. DOI:10.30957/lingua.v15i2.527.

Sagala, S, 2003, Konsep dan Makna Pembelajaran: Untuk Membantu Memecahkan Problematika Belajar dan Mengajar, Bandung: Alfabeta. 